\title{
Diretrizes para Submissão de Artigos
}

\section{Normas para submissão de artigos à Revista Brasileira de Sociologia}

A Revista Brasileira de Sociologia - RBS publica artigos em Ciências Sociais, preferencialmente em Sociologia. Os textos devem refletir a produção acadêmica e cientifica acerca da realidade brasileira e mundial contemporâneas. As matérias veiculadas na Revista deverão incluir artigos de natureza acadêmica e didática, registrando eventuais reedição de textos clássicos, literatura comentada sobre assuntos variados, textos de metodologia e reflexão sobre conceitos ou autores, hoje imprescindíveis ao profissional do ensino médio e superior.

A Revista é quadrimestral e aceita proposta de Dossiês, mediante Editais Públicos.

Artigos com temáticas diversificadas na área da RBS podem ser submetidos a qualquer data e em caráter de fluxo contínuo, através do e-mail_bsfluxo@gmail.

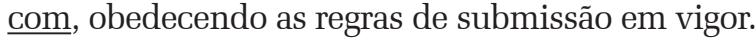

Considerando a desejada manutenção do alto padrão de qualidade e especialidade do periódico, todos os artigos a serem publicados são avaliados pelo sistema de pares (avaliação às cegas).

O envio espontâneo de qualquer colaboração implica automaticamente a cessão integral dos direitos autorais à RBS. 


\section{Condições para submissão}

Os artigos submetidos devem ser inéditos e devem assim permanecer durante a avaliação.

Como parte do processo de submissão, os autores são obrigados a verificar a conformidade da submissão em relação a todos os itens listados a seguir. As submissões que não estiverem de acordo com as normas serão devolvidas aos autores.

Os artigos não devem ultrapassar 50 mil caracteres com espaço, incluindo a bibliografia. O artigo deve ter resumo de 900 caracteres com espaço e 3 (três) palavras-chaves. Deve acompanhar, em arquivo separado, Nome completo do(s) autores(s), titulação, vinculo institucional, endereço.

Propostas de Dossiês devem ser enviadas com a apresentação da temática, sua relevância e abrangência para o campo dos estudos sociológicos. A proposta deve vir acompanhada dos dados dos proponentes: nome completo do(s) autores(s), titulação, vinculo institucional, endereço.

Os artigos submetidos devem conter resumo, titulo do artigo, e palavras-chaves em português e inglês.

As remissões bibliográficas no corpo do texto ou referências após citações a autores, devem seguir a forma (Autor, data) ou (Autor, data, página), como nos exemplos: (MILLS, 1960) ou (BENJAMIM, 1987,p. 205). Se houver mais de um título do mesmo autor no mesmo ano, eles são diferenciados por uma letra após a data: SIMMEL, 1965a), (SIMMEL, 1965b) etc.

A RBS apoia os esforços relativos à visibilidade das mulheres na produção acadêmica. Assim, as referências bibliográficas ao final do artigo devem conter o prenome das autoras e dos autores, não apenas suas iniciais, como se segue: 


\section{Referências bibliográficas:}

Livros:

LI, Peilin; SCALON, Celi; GORSHOKOV, Mikhail K.; SHARMA, Kumar (2013), Handbook on Social Stratification in the BRIC Countries: Change and Perspective. 1. ed. Cingapura/ Londres/New Jersey: World Scientific.

\section{Artigos:}

TOLBERT, Pamela S. (1986), "Organizations and inequality: Sources of earnings differences between male and female faculty". American Sociological Review n. 59, pp. 227-235.

Coletâneas:

INGRAM, Helen; SCHNEIDER, Anne I.; DELEON, Peter. (2007), "Social construction and policy design”. In: SABATIER, Paul A. (org.). Theories of the policy process. Cambridge, MA: Westview Press.

Teses Acadêmicas:

FORTUNA, Carlos. (1988), Threading Through: Cotton Production, Colonial Mozambique and Semiperipheral Portugal in the World-Economy. Tese de Doutorado. State University of New York - Binghamton. 